ACTA MYCOLOGICA

Vol. 48 (2): 155-171

2013
Dedicated to Professor Maria Ławrynowicz on the occasion of the 45th anniversary of her scientific activity

DOI: $10.5586 / \mathrm{am} .2013 .018$

\title{
Ectomycorrhizae of Tomentella badia: description and molecular identification
}

\author{
ANDREA BINDER ${ }^{1}$, DEREK PERŠOH ${ }^{2}$, NOUROU S. YOROU ${ }^{1}$, \\ RITA VERMA $^{1}$, CLAUS BÄSSLER ${ }^{3}$, and REINHARD AGERER ${ }^{1^{*}}$
${ }^{1}$ Department Biology I, Organismic Biology: Mycology, Universität München, Menzinger Str. 67, D-80638, München, *corresponding author: reinhard.agerer@bio.lmu.de ${ }^{2}$ Division Mycology, Universität Bayreuth, Universitätsstr. 30 / NWI, D-95440 Bayreuth ${ }^{3}$ Nationalpark Bayerischer Wald, Freyunger Str. 2, D-94481 Grafenau

Binder A., Peršoh D., Yorou N.S., Verma R., Bässler C., Agerer R.: Ectomycorrhizae of Tomentella badia: description and molecular identification. Acta Mycol. 48 (2): 155-171, 2013.

Species within the genera Tomentella are among the most important ECM in forests. However, our knowledge about their functional characteristics is still rather limited. The ectomycorrhizae of Tomentella badia on Picea abies are described here in detail and compared to the non-identified ECM Piceirhiza obscura. A pseudoparenchymatous mantle formed by epidermoid cells is covered by heaps of epidermoid cells. This mantle type is regarded as a new one and designated as mantle type R. Many cells filled with dark blue contents and/or blue granules, together with clampless hyphae, are distinct characters of these ectomycorrhizae. Molecular-phylogenetic analysis of the ITS region was used for identification.

Key words: ectomycorrhizae, anatomy, mantle type R, blue granules, molecular phylogeny, Piceirhiza obscura, Tomentella atramentaria

\section{INTRODUCTION}

Members of the family Thelephoraceae belong to the most important groups of ectomycorrhizae (ECM) formers (Kõljalg et al. 2000; Tedersoo et al. 2003; Agerer 2006; Tedersoo et al. 2007; Jakucs, Erős-Honti 2008; Wei, Agerer 2010). More than thirty ECM of the genus Tomentella have already been studied in detail (Wei, Agerer 2010). Regarding the general anatomical features of Tomentella ECM including its close relative Thelephora terrestris Pers., a few subgroups can be distinguished (Agerer 2006), as detailed in the following. Most of them are dark brown and have pseudoparenchymatous mantles, which also applies for a large number of other ECM (Agerer 2006). If they possess clamps and/or blue granules or blue cell walls, and/or show amyloid reaction at least of cell walls or septa of the inner surface of the mantle cap, they definitely belong to Thelephoraceae. This group may form cystidia or 
not. Lighter brownish ectomycorrhizae with cystidia may also belong to this family, particularly when they show clamps or amyloid reactions, like Thelephora terrestris. However, in such cases, additional fungal families have to be considered. Cystidia and amyloid reactions are known in the family Gomphidiaceae within Chroogomphus (Agerer 1990) and Gomphidius (Agerer 1990, 1991a), in Scutigeraceae within the genera Albatrellus (Agerer 1996; Agerer et al. 1996a) and Polyporoletus (Agerer et al. 1998), and in the family Bolbitiaceae, namely Descomyces (Agerer et al. 2001) and Descolea (Palfner 1997, 2001). But the ECM of the latter two genera are easily distinguishable from those of Tomentella by their special type of laterally tibiiform cystidia. Also a few Tomentella ECM of light colour, lacking cystidia and blue granules as well, can reveal amyloid reactions of hyphae, such as Tomentella brunneorufa M.J. Larsen (Agerer, Bougher 2001), and some still unidentified ECM that are very likely formed by members of Thelephoraceae (Agerer, Rambold 2004-2011). Patchy amyloidy occurs exceptionally also in Bankeraceae with Boletopsis leucomelaena (Pers.) Fayod (Agerer 1992), and in the presumptive member of Bankeraceae Pseudotomentella tristis (P. Karst.) M.J. Larsen (Agerer 1994). An amyloid reaction of almost the entire mantle is known in Cortinariaceae in Rozites caperatus (Pers.) P. Karst. (Agerer 1999) and Sclerodermataceae in Scleroderma sinnamarense Mont. (Ingleby 1999).

Here we present the description of a dark brown ECM with considerable amounts of blue granules, filling some mantle cells completely homogeneously blue. It lacks clamps and cystidia. Due to its anatomy it seems to belong to the genus Tomentella. DNA sequences corroborate this conclusion and reveal it as an ECM of Tomentella badia (Link) Stalpers. The ECM was found twice. The first time during a study focussing on changes in species composition and abundance of Norway spruce ECM in dependence on within-crown application of double concentrated ozone (Agerer 2012; Agerer et al. 2012), and a second time during a project studying species composition and abundance of ECM in an altitudinal transect of Norway spruce stands in the Nationalpark Bayerischer Wald (Bässler et al. 2009; Agerer 2012).

\section{MATERIAL AND METHODS}

Light microscope studies. ECM carefully isolated from soil samples and fixed for several months in FEA were used for microscopic preparations regarding mantle, features of emanating hyphae and for obtaining sections as detailed by Agerer (1991b). Drawings were performed at $1000 \times$ magnification using a drawing mirror connected to a LEICA Dialux 22 Digital Interference Contrast microscope. Habit sketches were made with the aid of a WILD M5 stereoscope, and photos with a computer-connected digital camera (KAPPA Image base).

DNA extraction, sequencing and PCR amplification. Total DNA was extracted from tiny root tips of the samples using the ChargeSwitch ${ }^{\circledR}$ gDNA Plant Kit (Invitrogen, Darmstadt, Germany) as recommended by the manufacturer, but downscaled (1:10). Polymerase chain reaction (PCR) amplification was performed for internal transcribed spacer ITS1, ITS2 and for the 5.8S region of the nuclear ribosomal RNA gene, using fungi-specific primer ITS1F (Gardes, Bruns 1993) and 
Basidiomycetes-specific primer ITS4B (White et al. 1990). PCR amplification was realised using the Ready To Go Beads (Amersham Pharmacia Biotech, Piscataway, NJ, USA), with a total of $24 \mu \mathrm{l}$ PCR solution composed of $15.4 \mu \mathrm{l} \mathrm{H} 2 \mathrm{O}, 1.0 \mu \mathrm{l} \mathrm{MgCl}$ (50 mM), $2.5 \mu$ l of $10 \times$ Buffer, $2.5 \mu \mathrm{l}$ dNTP mix (2mM/nucleotide), $1.25 \mu \mathrm{l}$ ITS1F $(10 \mathrm{pmol} / \mu \mathrm{l}), 1.25 \mu \mathrm{l}$ ITS4B $(10 \mathrm{pmol} / \mu \mathrm{l})$ and $0.1 \mu \mathrm{l} \mathrm{Taq}$ Polymerase $(5 \mathrm{U} / \mu \mathrm{l})$ and $1 \mu \mathrm{l}$ extracted DNA. To maximize the amplification (according to our experience various concentrations of PCR extract generated different thickness of DNA bands), PCR extract was diluted at 1:10 and 1:100. The different solutions were submitted to amplification. The amplification started with an initial denaturation step at $94^{\circ} \mathrm{C}$ for 2 min. This step was followed by 33 cycles of the following phases: denaturation $\left(95^{\circ} \mathrm{C}\right.$, $0.5 \mathrm{~min})$, primer annealing $\left(51^{\circ} \mathrm{C}, 1 \mathrm{~min}\right)$, elongation $\left(72^{\circ} \mathrm{C}, 2 \mathrm{~min}\right)$, and a final elongation phase at $72^{\circ} \mathrm{C}$ during 5-7 min. Addition of $16 \mu \mathrm{l} 100 \%$ isopropanol and 2.3 $\mu 15 \mathrm{M} \mathrm{NaCl}$ served to precipitate the amplicons over night at room temperature. Amplified PCR products $(2.5 \mu \mathrm{l})$ mixed with bromophenol blue $(1 \mu \mathrm{l})$ run on $1 \%$ agarose gels for $30-40 \mathrm{~min}$ at $95^{\circ} \mathrm{C}$, then stained in ethidium bromide for $10-15 \mathrm{~min}$ and afterwards in dd $\mathrm{H}_{2} \mathrm{O}$ for $30 \mathrm{sec}$. PCR products were then visualised under UVlight. Successful samples with clearly distinct DNA bands under UV-light were purified. To do this, the solution composed of $23 \mu \mathrm{l}$ PCR product of each sample were incubated with $16 \mu \mathrm{l}$ isopropanol (100\%) and $2.3 \mu \mathrm{l} \mathrm{NaCl}(5 \mathrm{M})$ over night at room temperature. The solutions were then centrifuged for $30 \mathrm{~min}$ at $14.000 \mathrm{rpm}\left(17^{\circ} \mathrm{C}\right)$. After the supernatant had been discarded, the pellet was washed with $50 \mu \mathrm{l}$ of $70 \%$ ethanol and centrifuged again at $14.000 \mathrm{rpm}\left(17^{\circ} \mathrm{C}\right)$ for $15 \mathrm{~min}$. Ethanol was discarded and the pellet was partly dried at room temperature for $30 \mathrm{~min}$. Finally, the

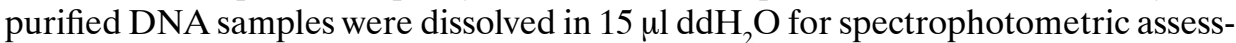
ment of DNA concentration (NanoDrop ND-1000, PeqLab). Solution of $60 \mu \mathrm{l}$, containing 30-40 ng of DNA, $1 \mu \mathrm{l}$ of ITS1F and $1 \mu$ ITS4B primer ( $2 \mathrm{mM}$, both) were then prepared for sequencing. DNA sequencing was performed by the sequencing service of the Department of Biology, genomic Service Unit (Ludwig-MaximiliansUniversität, Műnchen, Germany) using an ABI 3730 capillary sequencer.

Sequence processing, alignment and molecular phylogenetic analysis. The generated sequences were edited and analysed using the computer programme BioEdtit v7.0.5 (Hall 2005). Consensus sequences were generated for both specimens RA15279 and RA14908 and deposited in GenBank (NCBI) under the following accession numbers of KF876176 and KF876177 respectively. The most similar ITS sequences to both newly generated sequences were searched for in UNITE (Abarenkov et al. 2010) using the BLASTN search option (Altschul et al. 1997). Sequences of the 20 most similar taxa identified to species level were downloaded. Alternatively, we looked for the most similar sequence in GenBank using MEGABLAST (Zhang et al. 2000). Of the 50 most similar sequences, duplicate and/or unidentified sequences generated from environmental samples were ignored. Only sequences of fully identified taxa were considered. All downloaded sequences were automatically aligned against the newly generated sequences using the ClustalW Multiple Alignment option of BioEdit v.7.0.5. The alignment was manually checked and adjusted when necessary. Ambiguously aligned positions were excluded from the analysis. The dataset submitted to phylogenetic analyses included a total of 23 tomentelloid sequences with an alignment length of 588 characters. The most likely tree was calculated with 
the computer programme MEGA 5.1 (Tamaru et al. 2011) applying the General Time Reversible substitution model (GTR $+\mathrm{G}+\mathrm{I})$ with pairwise deletion of gaps, and the Nearest-Neighbour-Interchange (NNI) as the Maximum Likelihood heuristic method. The statistical support of branches was assessed by bootstrap analysis (Felsenstein 1985) of 1.000 replicates. The generated tree was edited with the FigTree v1.4 computer programme.

\section{RESULTS}

Tomentella badia (Link) Stalpers + Picea abies (L.) Karst.

\section{Short description}

This ectomycorrhiza is dark brown, densely grainy, with visible dots. The mantle is in plan view pseudoparenchymatous with epidermoid cells and reveals many blue granules that sometimes completely fill the cells. The outer layer is pseudoparenchymatous, with yellowish to brownish cell walls, occasionally greyish; blue granules occur predominantly within cells. The middle mantle represents a transitional type between pseudoparenchymatous and plectenchymatous. The inner mantle is a very thin plectenchymatous layer at the surface of the root, with adjacent elongated occasionally epidermoid-like shaped cells. Emanating hyphae are abundant, clampless, binding soil particles; occasionally blue wall patches and contents are present.

\section{Detailed description}

Morphological characters (Fig. 1a, Plate 1a, b). - Mycorrhizal systems irregularly monopodial-pinnate up to $8 \mathrm{~mm}$ long. - Main axes 0.5-0.6 mm diam. - Exploration type of the short distance category, hydrophilic. - Unramified ends straight, distal ends not inflated, cylindric, up to $5 \mathrm{~mm}$ long and $0.4-0.5 \mathrm{~mm}$ diam., dark greyish brown, at the very tips indistinctly lighter. - Surface of unramified ends densely grainy, covered with soil particles, shiny, cortical cells not visible, mycorrhiza not carbonizing, with brown dots. - Emanating hyphae abundant and not specifically distributed. - Rhizomorphs lacking. - Cystidia lacking. - Sclerotia lacking.

Anatomical characters of mantle in plan views (Figs 1b, c, 2, 3a, Plate 1c, d, e). Lacking are crystals, warts, and cell wall projections. - Outer mantle layers (Figs 1b, c, 2a, Plate 1c, d) pseudoparenchymatous, mantle matrix lacking; mantle hyphae forming epidermoid cells, mantle surface covered by mounds of cells (new mantle type $\mathrm{R}$ ); mound cells variable in shape, often epidermoid, cells (7.4)8.2-15.5-20.5(42.5) $\mu \mathrm{m}$ diam., (7.4)8.1-12.5-20(30) $\mu \mathrm{m}$ long, cell walls smooth, (0.2)0.4(0.6) $\mu \mathrm{m}$ thick and containing blue granules; mantle cells epidermoid, blue granules predominantly within cells or sometimes on cell surface, membranaceously yellowish to brownish, 

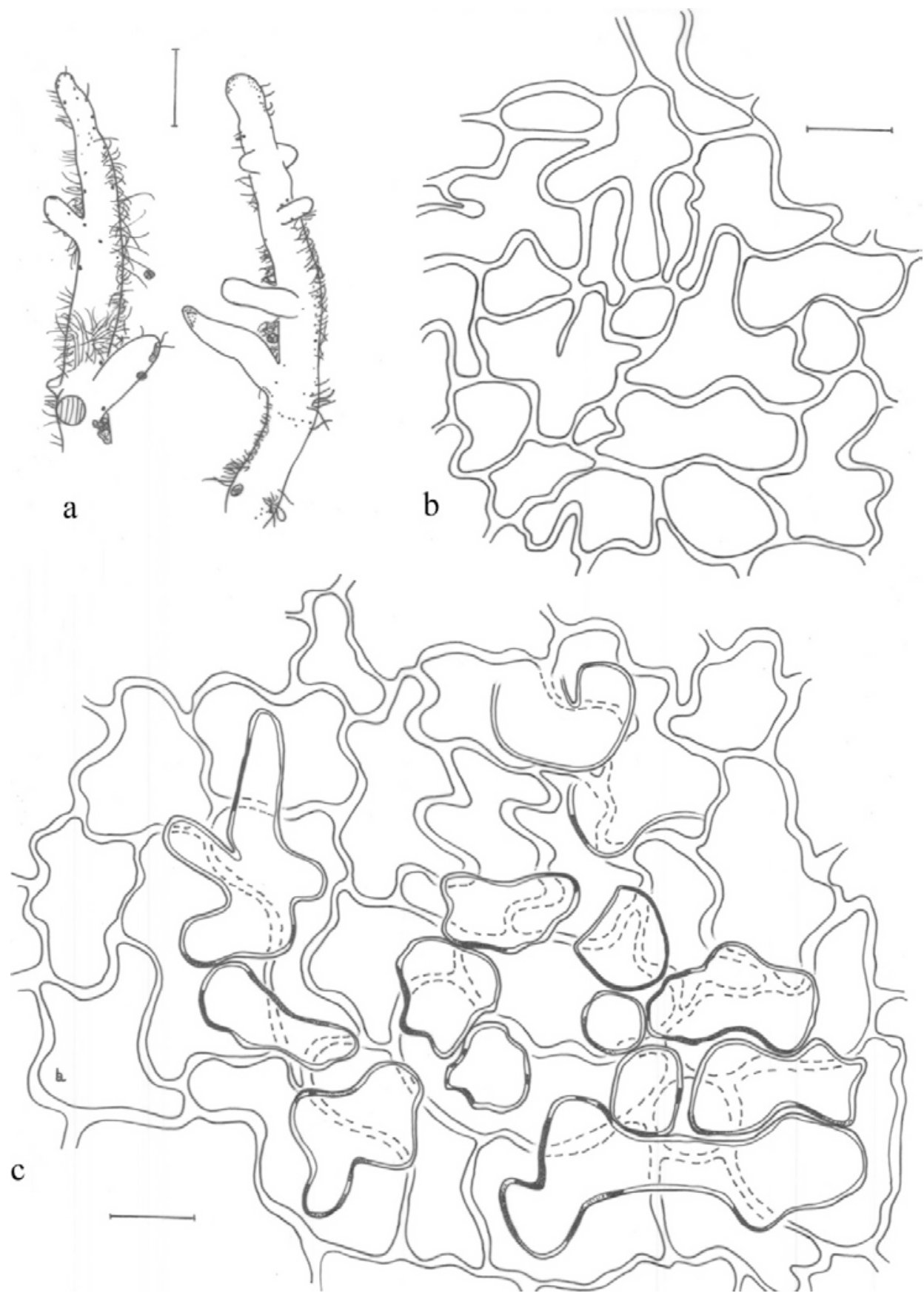

Fig. 1. Tomentella badia. a. Habit. b. Plan view of mantle with epidermoid cells. c. Surface view of mantle with epidermoid surface cells on the pseudoparenchyma with irregularly shaped to epidermoid cells; cell walls of the surface cells partially blue. Scale bar for habit $=1 \mathrm{~mm}$, for mantle $=10 \mu \mathrm{m}$ (all figs from RA15279). 


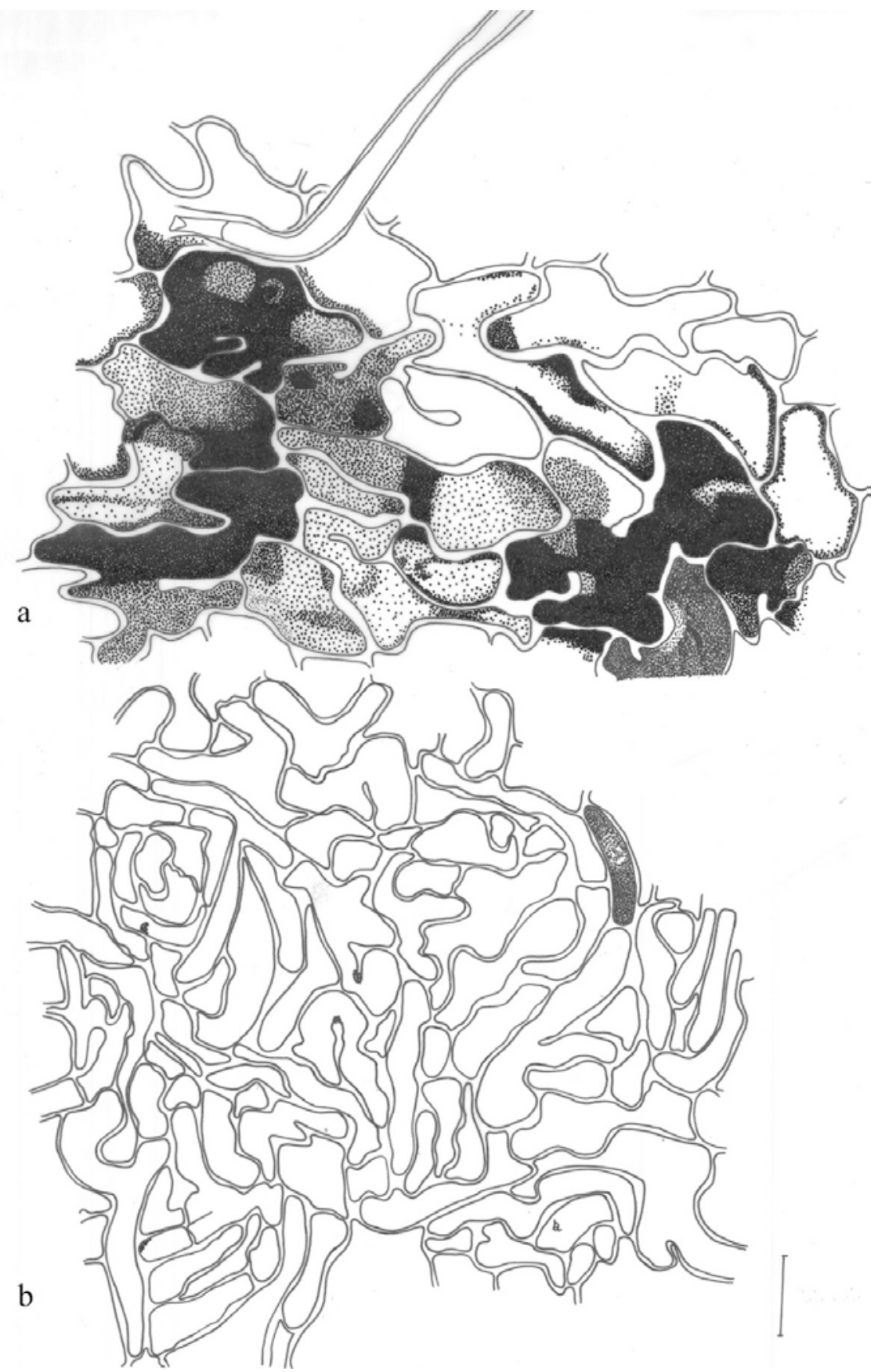

Fig. 2. Tomentella badia. a. Plan view of outer mantle layer; cells partially homogeneously filled by blue contents, partially with variously dense blue granules; clampless emanating hypha originating from a mantle cell. b. Plan view of inner mantle layer with elongated hyphoid to epidermoid cells, occasionally filled with blue granules. Scale bar $=10 \mu \mathrm{m}$ (all figs from RA 15279). 

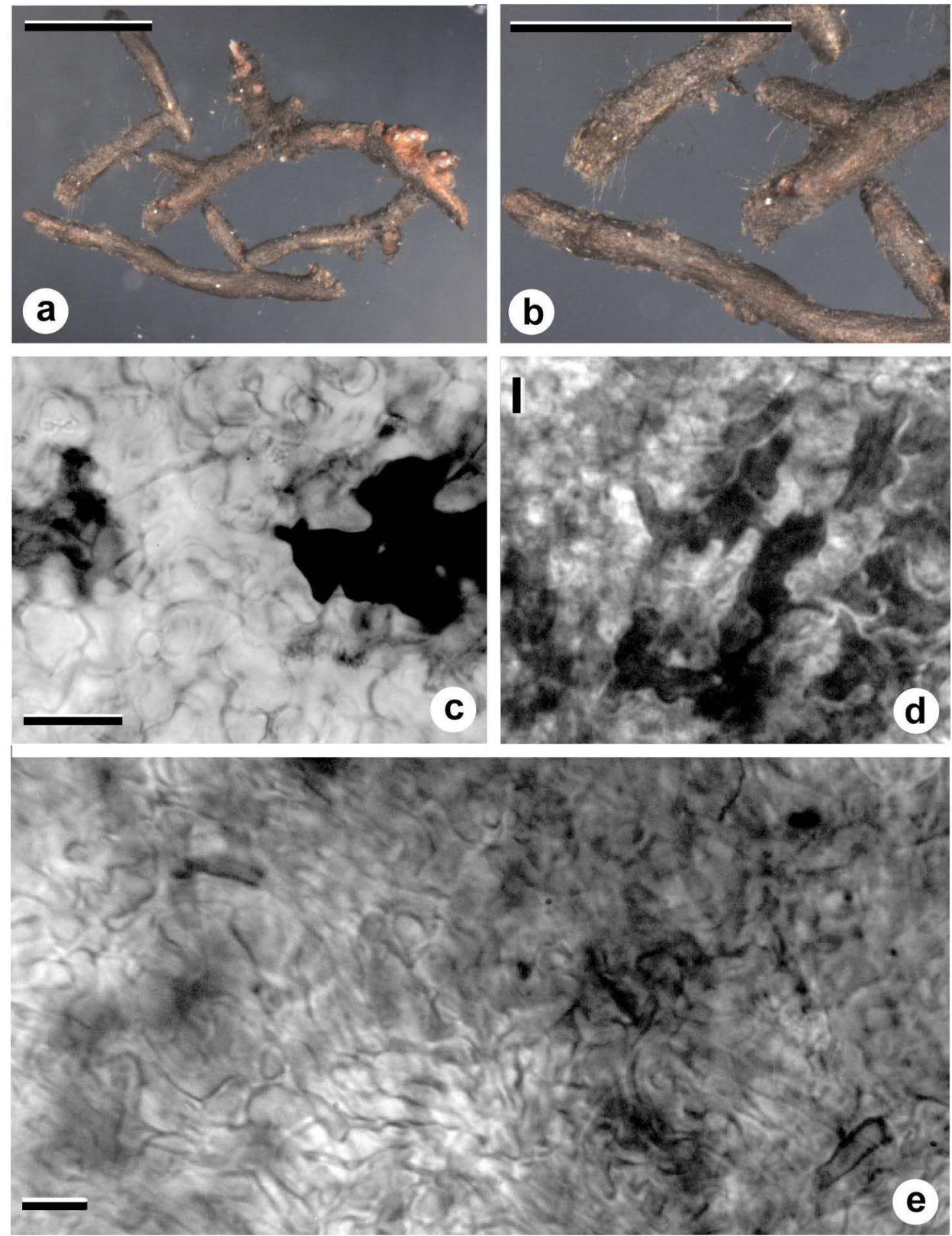

Plate 1. Tomentella badia. a, b. Habit. c, d. Mantle in plan view with epidermoid cells partially filled homogeneously blue, partially densely granularly blue, cell walls sometimes also blue. e. Plan view of inner mantle layer with blue patches of cells completely filled with blue contents, sometimes with blue granular contents, cell walls blue at places. Scale bar for a and $b=1 \mathrm{~mm}$, for $\mathrm{c}$ and $\mathrm{d}=10 \mu \mathrm{m}$ (all figs from RA 15279). 

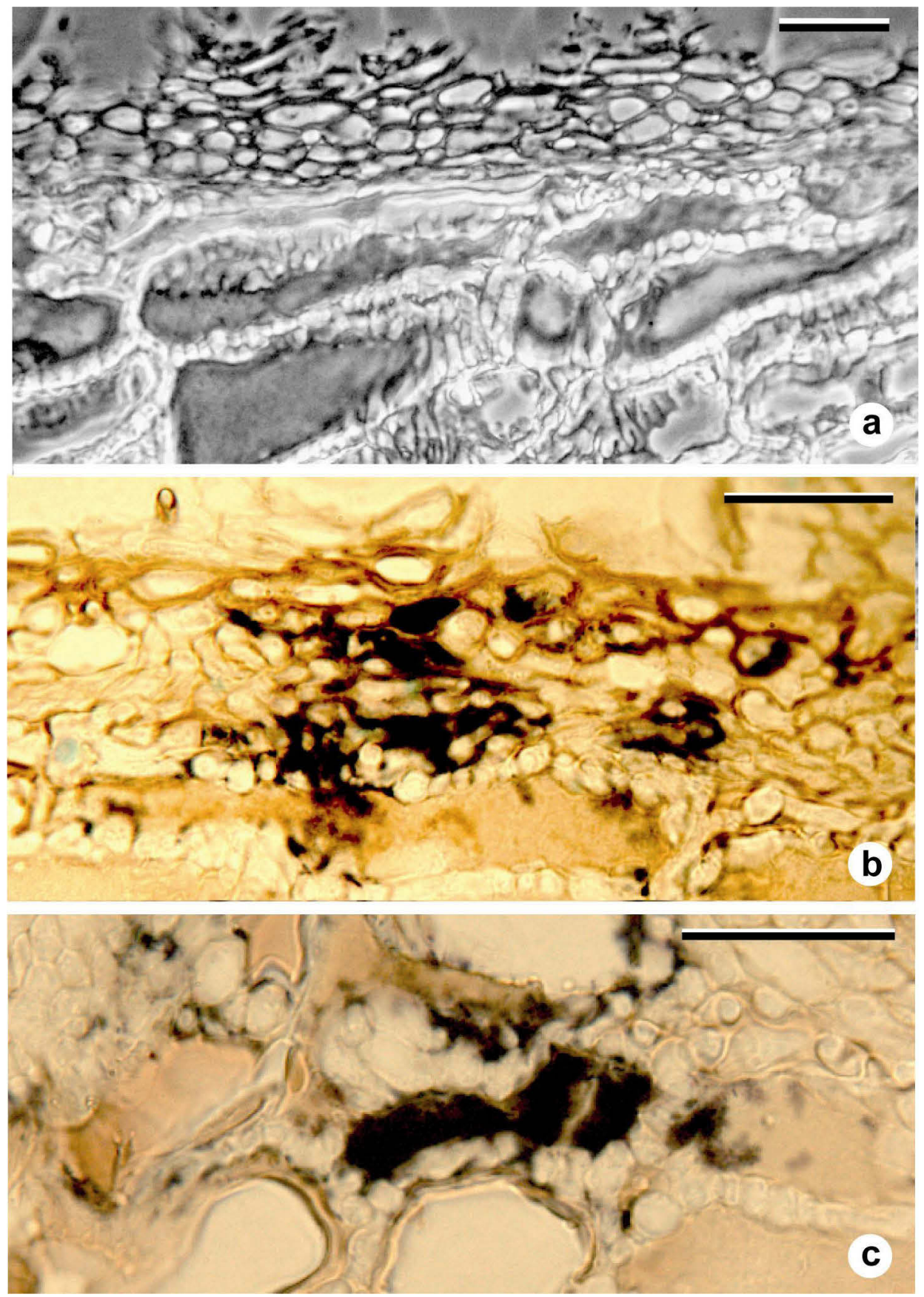

Plate 2. Tomentella badia. a. Median longitudinal section through ectomycorrhiza, from pseudoparenchymatous mantle with heaps of cells to Hartig net. b, c. Longitudinal section of ectomycorrhiza, Hartig net with cells completely filled by blue substances, which are apparently also deposited between the hyphal cells. Scale bar $f=10 \mu \mathrm{m}$ (all figs from RA 15279). 
cells (3)10-20(42) $\mu \mathrm{m}$ diam., (12)16-40(45) $\mu \mathrm{m}$ long, (3)4-7(8) in a square of $20 \times$ $20 \mu \mathrm{m}$, cell walls (0.4)1-2(3) $\mu \mathrm{m}$ thick, predominantly yellowish to brownish, occasionally greyish, smooth, clamps absent. - Middle mantle layers a transitional type between a plectenchyma and a pseudoparenchyma, with elongate epidermoid cells. - Inner mantle layers (Figs 2b, 3a, Plate 1e) of a very thin plectenchymatous layer at the surface of root, adjacent with roundish to epidermoid mostly distinctly elongated cells, membranaceously yellowish to brownish, without clamps, blue granules predominantly within cells or sometimes on cell surface, cells of pseudoparenchymatous areas (1.8)6-12-20(25) $\mu \mathrm{m}$ diam. and (2.7)4-16-30(35) $\mu \mathrm{m}$ long, (5)8-12(15) in an area of $20 \times 20 \mu \mathrm{m}$, cell walls smooth, (0.4)0.9-3(6) $\mu \mathrm{m}$ thick, predominantly yellowish to brownish, occasionally greyish. - Very tip like other parts of mantle.

Anatomical characters of emanating elements (Figs 3b, 4). - Lacking are crystals, clamps, warts, gelatinous matrix, drops of exuded pigment. - Emanating hyphae (Figs 3b, 4) straight, with intrahyphal hyphae and evenly distributed simple septa, ramification very infrequent, Y-shaped and in considerable distance from the septum, diameter of side branch at ramification points as thick as main part of branch; hyphae membranaceously yellowish to brownish, blue granules within the hyphae close to the inner surface or completely filling portions of the hyphae and sometimes also on the surface, 4.5-6(7) $\mu \mathrm{m}$ wide, cells (17)25-86(110) $\mu \mathrm{m}$ long; cell walls smooth, 0.5-1 $\mu \mathrm{m}$ thick, uneven in thickness, at the tip considerably thinner, ends not specialized; anastomoses not observed.

Anatomical characters, longitudinal section (Plate 2). - Mantle (22)25-35(40) $\mu \mathrm{m}$ wide apart from tip, with two layers. - Outer mantle layer pseudoparenchymatous, cells tangentially (6)9-26(30) $\mu \mathrm{m}$, radially (3)4-7(10) $\mu \mathrm{m}$. - Inner mantle layer pseudoparenchymatous, cells tangentially 4-10-20(27) $\mu \mathrm{m}$, radially (1)2-3(4) $\mu \mathrm{m}$. - Tannin cells present, in 1-2 rows, tangentially-oval to roundish and oriented in parallel to root axis, tannin cells tangentially (10)14-76(80) $\mu \mathrm{m}$, radially (6)9-20(23) $\mu \mathrm{m}$, $\mathrm{TCt}=42.1 \mu \mathrm{m}, \mathrm{TCq}=3.5$. - Cortical cells tangentially-oval to cylindrical and oriented in parallel to root axis, 4-5 rows, cortical cells tangentially (20)20-35-75(85) $\mu \mathrm{m}$, radially (14)16-27(30) $\mu \mathrm{m}, \mathrm{CCt}=44.4 \mu \mathrm{m}, \mathrm{CCq}=2.1$. Hartig net in section around tannin cells with beaded cells, in one row and 4-6(6.5) $\mu \mathrm{m}$ diam., around cortical cells beaded, in one row and 4-6(6.5) $\mu \mathrm{m}$ diam.; Hartig net down to the endodermis, Hartig net in plan view of palmetti type, lobes (1)1.5-2(2.5) $\mu \mathrm{m}$ broad, septa absent. - Haustoria not observed.

Colour reactions with different reagents. - Preparations of mantle: Melzer's reagent: no reaction (amyloidy not distinguishable because of the blue granules and blue patches of cell walls).

Reference specimen. Germany, Bayern, Nationalpark Bayerischer Wald, Zwieselerwaldhaus, plot T4 53, 1076 m a.s.l., on roots of Picea abies RA15279 (in M); myc. exc. and isol. R. Agerer, 18. 08. 2011. - Additional collection: Germany, Bayern, Lkr. Freising, Kranzberger Forest, close to Thalheim, $490 \mathrm{~m}$ a.s.l., double ambient ozone treated plot, on roots of Picea abies, cores B4O (RA14907 in M), D7O (RA14908 in M), myc. exc. and isol. R. Agerer, 08. 05. 2009. 
a
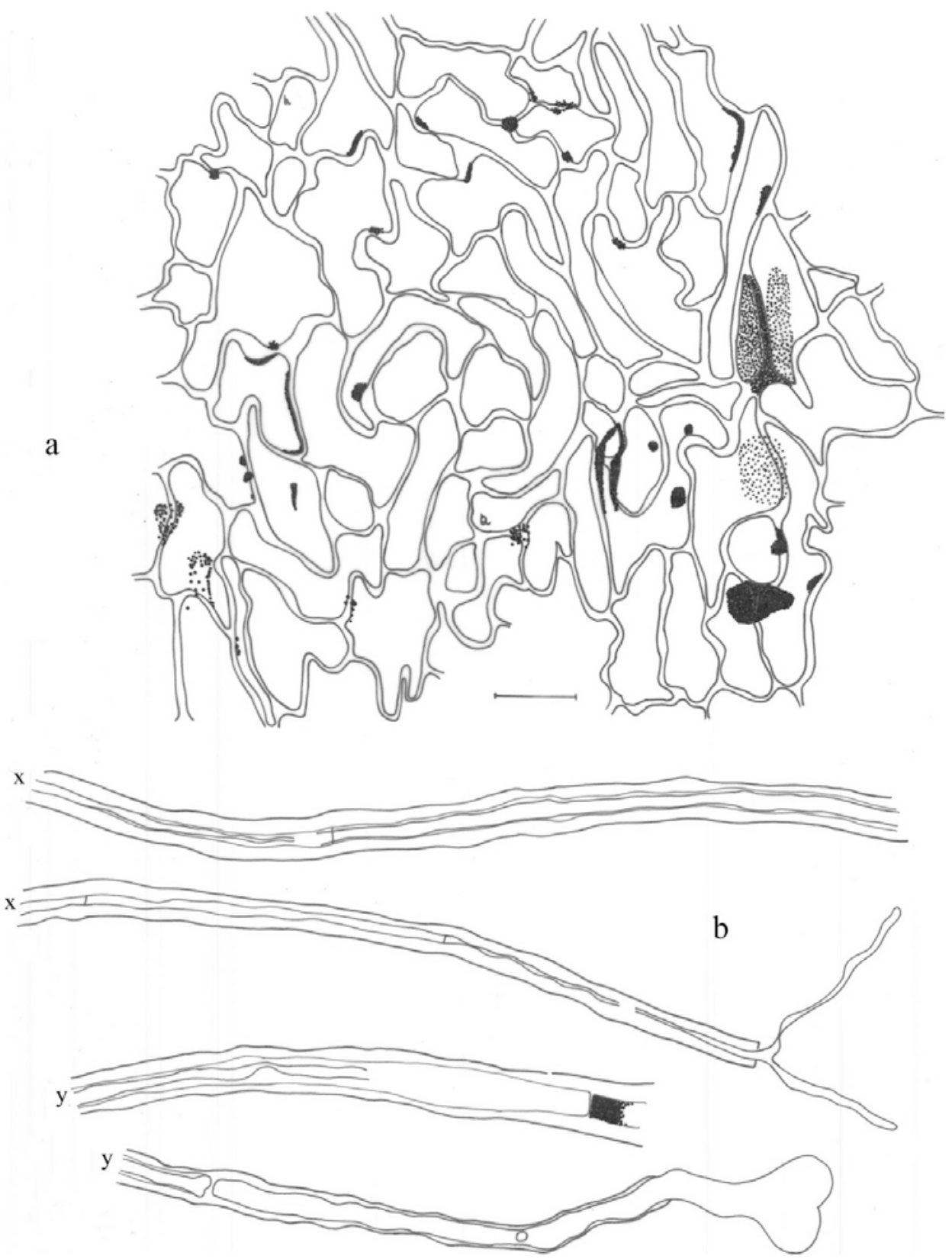

Fig. 3. Tomentella badia. a. Plan view of inner mantle layer with elongated hyphoid to epidermoid cells, partially filled with variously dense blue granules, predominantly within cells. $b$. Emanating hyphae with intrahyphal hyphae growing out of the parent hypha as a thin ramified hypha and as an inflated portion; note the homogeneously blue portion below a simple septum. Scale bar $=10 \mu \mathrm{m} ; \mathrm{x}$ and $\mathrm{y}$ indicate point of continuation of the hyphae depicted in two portions; (all figs from RA 15279). 


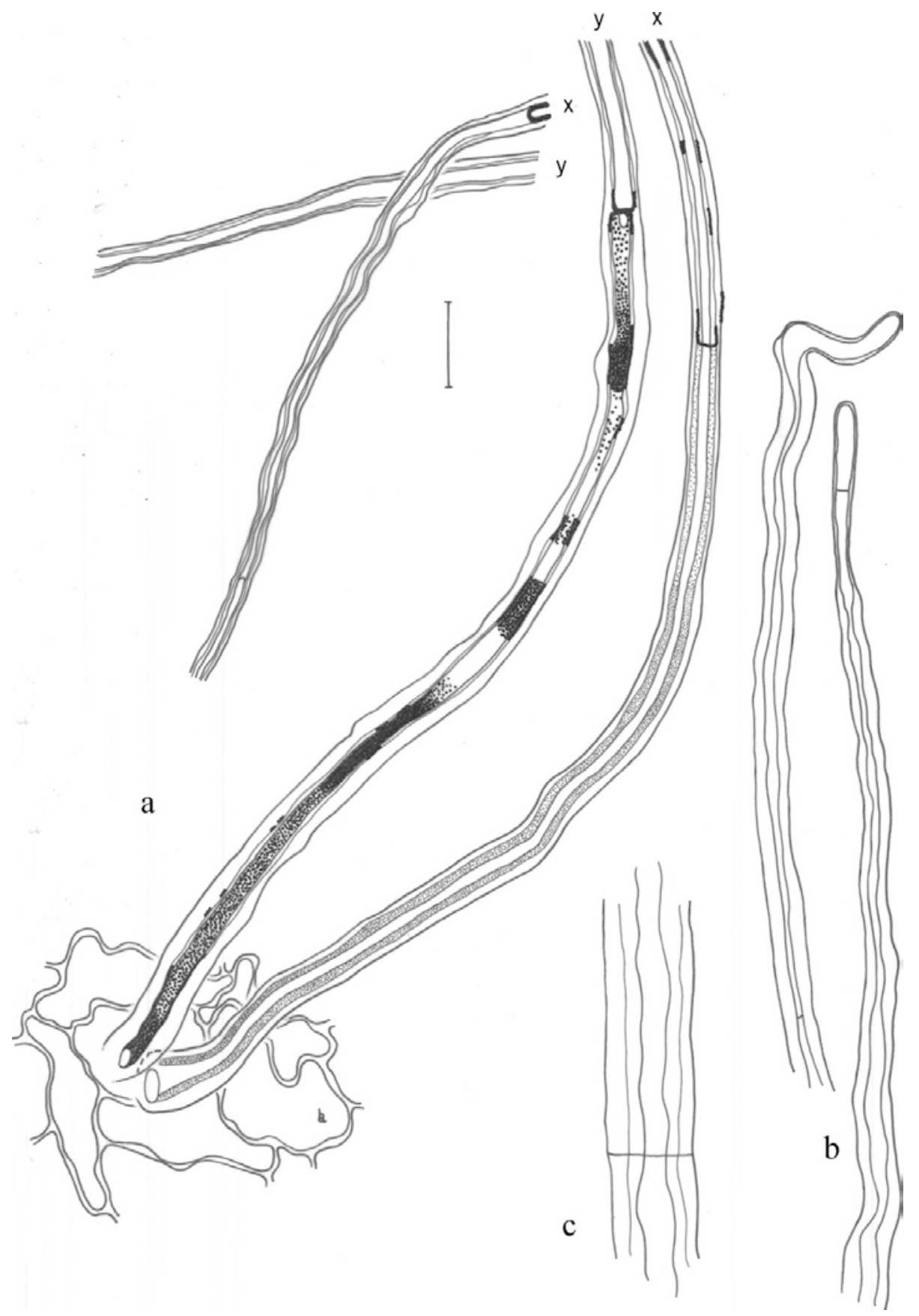

Fig. 4. Tomentella badia. a. Emanating hyphae partially filled homogenously blue or with variously dense blue granules, their proximal ends connected to a mantle cell. b. Distal ends of emanating hyphae. c. Detail of an emanating hypha with an intrahyphal hypha. Scale bar for $\mathrm{a}$ and $\mathrm{b}=10 \mu \mathrm{m}$, for $\mathrm{c}=20 \mu \mathrm{m} ; \mathrm{x}$ and $\mathrm{y}$ indicate point of continuation of the hyphae depicted in two portions; (all figs from RA 15279). 


\section{Sequence analysis and phylogenetic placement of the ectomycorrhizae}

The BLASTN search in GenBank and UNITE revealed Tomentella badia (accession numbers UDB001656, UDB000952, UDB000238, UDB000239) and one unidentified Tomentella species (UDB001663) as the most similar taxa to both specimens RA15279 and RA14908 with identity rate between 98 and 99\%. The next most similar species is Tomentella atramentaria Rostr. (UDB00235, UDB000236 and UDB000240) with lower identity rates of 95 to $97 \%$. From GenBank, we obtained numerous sequences of uncultured environmental samples, among them sequences FJ816765 and FN565374 are the most similar (identity rates of 99 and $98 \%$ respectively). The best matching and taxonomically fully annotated sequence was JQ888211 (Tomentella badia) which shows a similarity of $99 \%$ with the sequence from sample RA14908 and of 98\% with RA15279.

Both sequences, RA15279 and RA14908, cluster together in a terminal clade that is supported by a bootstrap value of $95 \%$ in the molecular-phylogenetic analyses (Fig. 5). They form the sister clade to Tomentella badia (UDB001656) and the monophyletic origin of these 3 sequences is supported by a bootstrap support of $74 \%$. All six specimens of Tomentella badia included in the analysis and ECM RA15279 and RA14908 cluster together as a monophyletic group with a strong bootstrap (84\%).

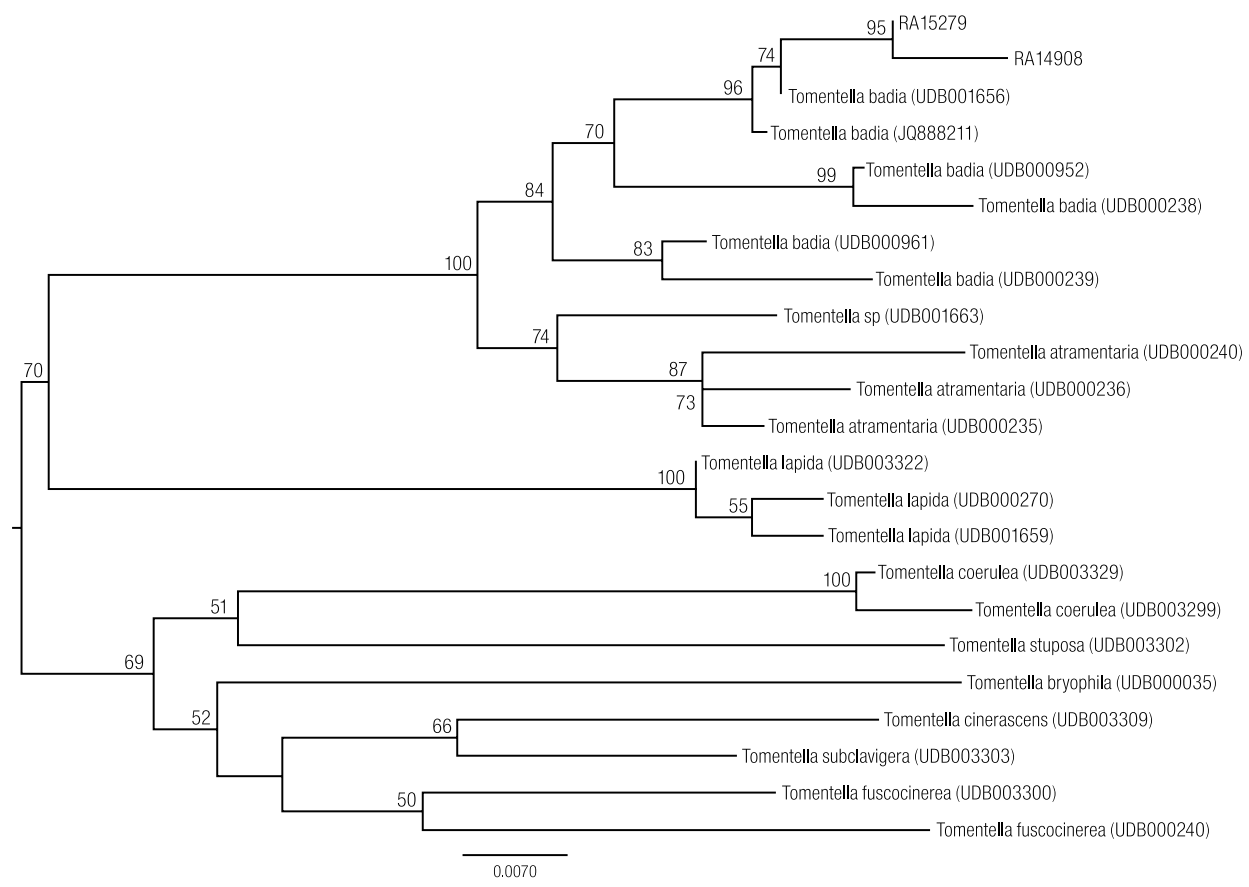

Fig. 5. Phylogram inferred from the Maximum Likelihood of 23 tomentelloid ITS sequences showing the affiliation of the samples of the present study to Tomentella badia. Bootstrap values $(>50 \%)$ are indicated by relevant nodes. GenBank (UNITE and NCBI) accession numbers of selected species are given after species names. The bar indicates the number of substitution per site. 
The sister clade of this T. badia complex is composed of Tomentella atramentaria and a not further identified Tomentella sp. (UDB0001663).

\section{DISCUSSION}

The ECM of Tomentella badia belongs to a group of tomentelloid fungi that are dark brown (Agerer, Rambold 2004-2011), many of which are still not identified, which underlines the importance to reinforce such studies (in inverted commata): 'Dryadirhiza nigra' (Harrington, Mitchell 2002), 'Fagirhiza asteromustrata' (Jakucs et al. 2008), 'F. setifera' (Brand 1991), 'F. fusca' (Brand 1991), 'F. spinulosa' (Brand 1991), 'Piceirhiza obscura' (Gronbach 1988), 'Pinirhiza acuminata” (Wei, Agerer 2010), 'P. heilihensis' (Wei, Agerer 2010), Pseudotomentella humicola M. J. Larsen (di Marino et al. 2007), 'Pseudotsugaerhiza tomentelloidea' (Judenmann et al. 2012), 'Quercirhiza auraterocystidiata' (Azul et al. 2006a), 'Q. cumulosa' (de Roman 2002), 'Q. nodulosomorpha' (Azul et al. 1999), 'Q. squamosa' (Palfner, Agerer 1996), 'Q. stellata' (de Roman et al. 2002), 'Q. tomentellocystidiata' (Azul et al. 2006b), 'Q. tomentelloepidermoidea' (Azul et al. 2008a), 'Q. tomentelloflexuosa' (Azul et al. 2006c), 'Q. tomentellofuniculosa' (Azul et al. 2006d), 'Q. tomentellostellata' (Azul et al. 2008b), Tomentella sublilacina (Ellis \& Holw.) Wakef. (Agerer 1996b, sub n. T. albomarginata (Bourdot \& Galzin) M.P. Christ.), T. ferruginea (Pers.) Pat. (Raidl, Müller 1996), and T. stuposa (Link) Stalpers (Jakucs et al. 2005, incl. 'Piceirhiza nigra' (Gronbach 1988), 'Populirhiza asperula' (Jakucs et al. 2005; Agerer, Rambold 2004-2011), and 'Piceirhiza nigripunctata' (Agerer et al. 2002).

From all these ECM only one species reveals the combination of a pseudoparenchymatous mantle and lacking clamps: 'Piceirhiza obscura'. This ECM is very similar to that of Tomentella badia with respect so several features. Both have a pseudoparenchymatous mantle with epidermoid cells, clampless emanating hyphae and heaps of cells on the mantle surface. Gronbach (1988) reported on "black, crystalloid depositions and dark patches in regular distances" of these ECM that might be indicative of the dark bluish black granules and contents of some cells as shown for T. badia ECM. But the feature of blue granules was not known to Gronbach during that time. She did not mention the shape of the heap cells. Mantle cells of ' $P$. $o b$ scura' are smaller than those of T. badia (4-5 $\mu \mathrm{m}$ vs. 6-20 $\mu \mathrm{m})$ and the cell walls are thinner $(0.5 \mu \mathrm{m}$ vs. up to $3 \mu \mathrm{m})$. Differences are obvious with respect to the emanating hyphae, too. The cell walls of those of T. badia are up to $2 \mu \mathrm{m}$ thick, in ' $P$. obsura' only up to $1 \mu \mathrm{m}$. Whereas the hyphal walls are smooth in T. badia ECM, those of ' $P$. obscura' are minutely rough. The "occasionally present black crystalloid depositions within the emanating hyphae" are possibly identical to the blue granules found in emanating hyphae of T. badia. Contrary to T. badia, the mantle of P. obscura occasionally formed acuminate, thick-walled and slightly bent cystidia.

In comparison to the ECM, fruitbodies of T. badia are only greyish brown and reveal no blue colours. However, Dämmrich (2006) depicts dark spots on the surface of basidia and subhymenium hyphae, which are not mentioned in the description of the species. Kõljalg (1996) describes basidia and subhymenium as cyanescent, what indicates that the granules become bluish with $\mathrm{KOH}$. But the dark bluish black 
colour of T. badia ECM does not change to greenish blue in $\mathrm{KOH}$. This is possibly due to former fixation of the ECM in FEA.

The dark blue granules and homogeneous bluish black contents are very likely formed by thelephoric acid, a characteristic pigment of apparently all Thelephoraceae (Bresinsky, Rennschmid 1971; Gill, Steglich 1987). Gill and Steglich (1987) mention a dark violet colour for the purified substance. Agerer et al. (1995) report on the presence of thelephoric acid in the blue granules containing ECM 'Piceirhiza nigra'.

Finally, the deviating features of T. badia ECM and 'Piceirhiza obscura' regarding cell diameter and cell wall thickness of mantle cells and emanating hyphae, surface of emanating hyphae and absence/presence of cystidia indicate that very likely ' $P$. obscura' ECM are not formed by T. badia. However, DNA sequence comparisons should be performed to support this conclusion.

The DNA-ITS-phylogram shows that Tomentella badia forms a separate clade which is sister group to Tomentella atramentaria Rostr. (Fig. 5). Tomentella atramentaria is known to form ECM (Krpata et al. 2008; Mühlmann et al. 2008), but no characterization of its ECM is available yet. As the fruitbodies of T. atramentaria are brown in colour without any indication of blue granular deposits (Kõljalg 1996; Dämmrich 2006) and have clamps in the subiculum, the ECM of T. atramentaria will certainly be different from those of T. badia, revealing simple septa and distinct blue contents. Only the cyanescent reaction of $T$. atramentaria is somewhat reminiscent of possibly higher contents of thelephoric acid in comparison to many other species of this genus. The close relationship of T. badia with T. atramentaria, the presence of clamps and the cyanescent reaction of 'Piceirhiza obscura' might be indicative that this non-identified ECM could be formed by $T$. atramentaria. The sister group to the clade of T. badia and T. atramentaria is formed by Tomentella lapida (Pers.) Stalpers, of which ECM descriptions are not available.

Acknowledgements. We highly appreciate the help of our technicians Edmund Marksteiner, Claudia Bubenzer-Hange and Anina Neumann. Financial support was provided by Nationalpark Bayerischer Wald.

\section{REFERENCES}

Abarenkov K., Nilsson R.H., Larsson K.-H., Alexander I.J., Eberhardt U., Erland S., Høland K., Kjøller R., Larsson E., Pennanen T., Sen R., Taylor A.F.S., Tedersoo L., Ursing B.M., Vrålstad T., Liimatainen K., Peintner U., Kõljalg U. 2010. The UNITE database for molecular identification of fungi - recent updates and future perspectives. New Phytol. 186: 281-285. http://dx.doi.org/10.1111\%2Fj.14698137.2009.03160.x

Agerer R. 1990. Studies on ectomycorrhizae XXIV. Ectomycorrhizae of Chroogomphus helveticus and C. rutilus (Gomphidiaceae, Basidiomycetes) and their relationship to those of Suillus and Rhizopogon. Nova Hedwigia 50: 1-63.

Agerer R. 1991a. Studies on ectomycorrhizae XXXIV. Mycorrhizae of Gomphidius glutinosus and of G. roseus with some remarks on Gomphidiaceae (Basidiomycetes). Nova Hedwigia 53: 127-170.

Agerer R. 1991b. Characterization of ectomycorrhiza. (In:) J.R. Norris, D.A. Read, A.K. Varma (eds). Techniques for the study of mycorrhiza. Methods in Microbiology, 23. Academic Press: 25-73.

Agerer R. 1992. Studies on ectomycorrhizae XLIV. Ectomycorrhizae of Boletopsis leucomelaena (Thelephoraceae, Basidiomycetes) and their relationship to an unidentified ectomycorrhiza. Nova Hedwigia 55: 501-518.

Agerer R. 1994. Pseudotomentella tristis (Thelephoraceae). Eine Analyse von Fruchtkörper und Ektomykorrhizen. Z. Mykol. 60: 143-158. 
Agerer R. 1996a. Albatrellus ovinus (Schaeff.: Fr.) Kotl. \& Pouz. + Picea abies (L.) Karst. Descr. Ectomyc. 1: $23-28$.

Agerer R. 1996. Ectomycorrhizae of Tomentella albomarginata (Thelephoraceae) on Scots pine. Mycorrhiza 6: 1-7. http://dx.doi.org/10.1007\%2Fs005720050098

Agerer R. 1999. Rozites caperatus (Pers.: Fr.) Karst. + Pinus sylvestris L. Descr. Ectomyc. 4: 109-113.

Agerer R. 2006. Fungal relationships and structural identity of their ectomycorrhizae. Mycol. Progress 5: 67-107. http://dx.doi.org/10.1007\%2Fs11557-006-0505-x

Agerer R. 2012. Asexual reproduction of Hygrophorus olivaceoalbus by intracellular microsclerotia in root cells of Picea abies - A winner of ozone stress? Mycol. Progress 11: 425-434. http://dx.doi. org/10.1007\%2Fs11557-011-0757-y

Agerer R., Bougher N.L. 2001. Tomentella brunneorufa M. J. Larsen + Eucalyptus spec. Descr. Ectomyc. 5: 205-212.

Agerer R., Rambold G. 2004-2011. [last update 2011-02-11] DEEMY - An Information System for Characterization and Determination of Ectomycorrhizae. www.deemy.de München, Germany.

Agerer R., Beenken L., Ammirati J. 1998. Polyporoletus sublividus Snell + Abies amabilis Forb. Descr. Ectomyc. 3: 85-91.

Agerer R., Beenken L., Bougher N.L. 2001. Descomyces albus (Klotzsch) Bougher \& Castellano + Eucalyptus spec. Descr. Ectomyc. 5: 41-47.

Agerer R., Grote R., Raidl S. 2002. The new method 'micromapping', a means to study species-specific associations and exclusions of ectomycorrhizae. Mycol. Progress 1: 155-166. http://dx.doi. org/10.1007\%2Fs11557-006-0015-x

Agerer R., Klostermeyer D., Steglich W. 1995. Piceirhiza nigra, an ectomycorrhiza on Picea abies formed by a species of Thelephoraceae. New Phytol. 131: 377-380. http://dx.doi. org/10.1111\%2Fj.1469-8137.1995.tb03074.x

Agerer R., Klostermeyer D., Steglich W., Franz F., Acker G. 1996. Ectomycorrhizae of Albatrellus ovinus (Scutigeraceae) on Norway spruce with some remarks on the systematic position of the family. Mycotaxon 59: 289-307.

Agerer R., Hartmann A., Pritsch K., Raidl S., Schloter M., Verma R., Weigt R. 2012. Plants and Their Ectomycorrhizosphere: Cost and Benefit of Symbiotic Soil Organisms. (In:) R. Matyssek, H. Schnyder, W. Oßwald, D. Ernst, J. C. Munch, H. Pretzsch (eds). Growth and Defence in Plants, Ecological Studies 220, Springer-Verlag Berlin Heidelberg: 213-242.

Altschul S.F., Madden T.L., Schaffer A.A., Zhang J., Zhang Z., Miller W., Lipman D.J. 1997. Gapped BLASTN and PSI-BLAST: a new generation of protein data base search programs. Nucleic Acids Res. 25: 3389-3402.

Azul A.M., Agerer R., Martin P.M., Freitas H. 2006a. “Quercirhiza auraterocystidiata” + Quercus suber L. Descr. Ectomyc. 9/10: 81-86.

Azul A.M, Agerer R., Freitas H. 2006b. "Quercirhiza tomentellocystidiata" + Quercus suber L. Descr. Ectomyc. 9/10: 115-119.

Azul A.M., Agerer R., Freitas H. 2006c. "Quercirhiza tomentelloflexuosa” + Quercus suber L. Descr. Ectomyc. 9/10: 121-126.

Azul A.M., Agerer R., Martin P.M., Freitas H. 2006d. "Quercirhiza tomentellofuniculosa” + Quercus suber L. Descr. Ectomyc. 9/10: 127-134.

Azul A.M., Agerer R., Martin P.M., Freitas H. 2008a. "Quercirhiza tomentelloepidermoidea" + Quercus suber L. Descr. Ectomyc. 11/12: 131-134.

Azul A.M., Agerer R., Martin M.P., Freitas H. 2008b. “Quercirhiza tomentellostellata” + Quercus suber L. Descr. Ectomyc. 11/12: 141-146.

Bässler C., Förster B., Moning C., Müller J. 2009. The BIOKLIM Project: Biodiversity research between climate change and wilding in a temperate montane forest - The conceptual framework. Waldökol. Landschaftsforsch. Naturschutz 7: 21-34.

Brand F. 1991. Ektomykorrhizen an Fagus sylvatica. Charakterisierung und Identifizierung, ökologische Kennzeichnung und unsterile Kultivierung. Libri Botanici 2: 1-229.

Bresinsky A., Rennschmid A. 1971. Pigmentmerkmale, Organisationsstufen und systematische Gruppen bei Höheren Pilzen. Bericht der Deutschen Botanischen Gesellschaft 84: 313-329.

Dämmrich F. 2006. Studien der tomentelloiden Pilze in Deutschland - unter besonderer Berücksichtigung der Zeichnungen von Frau Dr. H. Maser aus den Jahren 1988-1974. Teil 1: Die Gattung Tomentella. Z. Mykol. 72: 167-212. 
de Román M .2002. «Quercirhiza cumulosa” + Quercus ilex L. subsp. ballota (Desf.) Samp. Descr. Ectomyc. 6: 13-18.

de Román M. Agerer R. de Miguel A. 2002. «Quercirhiza stellata" + Quercus ilex L. subsp. ballota (Desf.) Samp. Descr. Ectomyc. 6: 19-24.

Felsenstein J. 1985. Confidence limits on phylogenies: an approach using the bootstrap. Evolution 39: 783-791.

Gardes M., Bruns T.D. 1993. ITS primers with enhanced specificity for Basidiomycetes. Application to the identification of mycorrhizas and rusts. Mol. Ecol. 2: 113-118. http://dx.doi.org/10.1111\%2Fj.1365294X.1993.tb00005.x

Gill M., Steglich W. 1987. Pigments of Fungi (Macromycetes). (In:) W. Herz, H. Grisebach, G.W. Kirby, C. Tamm (eds). Progress in the Chemistry of Organic Natural Products, 51. Springer, Wien, New York: 1-317.

Gronbach E. 1988. Charakterisierung und Identifizierung von Ektomykorrhizen in einem Fichtenbestand mit Untersuchungen zur Merkmalsvariabilität in sauer beregneten Flächen. Bibliotheca Mycologica, 125, Cramer, Berlin, Stuttgart.

Hall T. 2005. BioEdit, biological sequence alignment editor for Win95/98/NT/2K/XP. Carlsbad, California: Ibis therapeutic.

Harrington T.J., Mitchell D.T. 2002. Characterization of Dryas octopetala ectomycorrhizas from limestone karst vegetation, western Ireland. Can. J. Bot. 80: 970-982. http://dx.doi.org/10.1139\%2Fb02-082

Ingleby K. 1999. Scleroderma sinnamarense Mont. + Gnetum africanum Welw. Descr. Ectomyc. 4: 127133.

Jakucs E., Kovacs G.M., Agerer R., Romsics C., Erös-Honti Z. 2005. Morphological-anatomical characterization and molecular identification of Tomentella stuposa ectomycorrhizae and related anatomotypes. Mycorrhiza 15: 247-258. http://dx.doi.org/10.1007\%2Fs00572-004-0326-1

Jakucs E., Erös-Honti Z. 2008. Morphological-anatomical characterization and identification of Tomentella ectomycorrhizas. Mycorrhiza 18: 277-285. http://dx.doi.org/10.1007\%2Fs00572-008-0183-4

Jakucs E., Ganyec S., Erös-Honti Z. 2008. "Fagirhiza asteromustrata” + Fagus sylvatica. Descr. Ectomyc. 11/12: 31-35.

Judenmann D., Peršoh D., Agerer R. 2012. Pseudotsugaerhiza tomentelloidea + Pseudotsuga menziesii (Mirb.) Franco. Descr. Ectomyc. 13: 81-90.

Kõljalg U. 1996. Tomentella (Basidiomycota) and related genera in temperate Eurasia. Fungiflora, Oslo.

Kõljalg U., Dahlberg A., Taylor A.F.S., Larsson E., Hallenberg N., Stenlid J., Larsson K.-H., Fransson P.M., Karén O., Jonsson L. 2000. Diversity and abundance of resupinate thelephoroid fungi as ectomycorrhizal symbionts in Swedish boreal forests. Mol. Ecol. 9: 1985-1996. http://dx.doi. org/10.1046\%2Fj.1365-294X.2000.01105.x

Krpata D., Peintner U., Langer I., Fitz W.J., Schweiger P. 2008. Ectomycorrhizal communities associated with Populus tremula growing on a heavy metal contaminated site. Mycol. Res. 112: 1069-1079.

Mülmann O., Bacher M., Peintner U. 2008. Polygonum viviparum mycobionts on an alpine primary successional glacier front. Mycorrhiza 18: 87-95. http://dx.doi.org/10.1007\%2Fs00572-0070156-z Palfner G. 1997. Descolea antarctica Singer + Nothofagus alpina (Poepp. et Endl.) Oerst. Descr. Ectomyc. 2: 7-12.

Palfner G. 2001. Taxonomische Studien an Ektomykorrhizen aus den Nothofagus-Wäldern Mittelsüchiles. Bibliotheca Mycologica 190, Cramer, Berlin Stuttgart.

Raidl S., Müller W.R. 1996. Tomentella ferruginea (Pers.) Pat. + Fagus sylvatica L. Descr. Ectomyc. 1: 161-166.

Tamura K., Peterson D., Peterson N., Stecher G., Nei M., Kumar S. 2011. MEGA5: Molecular Evolutionary Genetics Analysis using Maximum Likelihood, Evolutionary Distance, and Maximum Parsimony Methods. Molecular Biology and Evolution 28: 2731-2739. http://dx.doi. org/10.1093\%2Fmolbev\%2Fmsr121

Tedersoo L., Kõljalg U., Hallenberg N., Larsson K.-H. 2003. Fine scale distribution of ectomycorrhizal fungi and roots across substrate layers including coarse woody debris in a mixed forest. New Phytol. 159: 153-165. http://dx.doi.org/10.1046\%2Fj.1469-8137.2003.00792.x

Tedersoo L., Suvi T., Beaver K., Kõljalg U. 2007. Ectomycorrhizal fungi of the Seychelles: diversity patterns and host shifts from the native Vateriopsis seychellarum (Dipterocarpaceae) and Intsia bijuga (Caesalpiniaceae) to the introduced Eucalyptus robusta (Myrtaceae), but not Pinus caribea (Pinaceae). New Phytol. 175: 321-333. http://dx.doi.org/10.1111\%2Fj.1469-8137.2007.02104.x 
Wei J., Agerer R. 2010. Three ectomycorrhizae of Thelephoraceae on Chinese pine (Pinus tabulaeformis) and a key to thelephoroid ectomycorrhizae. Nova Hedwigia 91: 165-186.

White T.J., Bruns T.D., Lee S.B., Taylor J.W. 1990. Analysis of phylogenetic relationships by amplification and direct sequencing of ribosomal RNA genes. (In:) M.A. Innis, D.H. Gelfand, J.N. Sninsky, T.J. White (eds). PCR Protocols: a guide to method and applications. Academic Press, San Diego: 315-322.

Zhang Z., Schwarz S., Wagner L., Miller W. 2000. A greedy alogarithm for aligning DNA sequences. J. Comput. Biol. 7: 203-214. 